\title{
The Effect of Tax Payer Awareness, Taxation Knowledge and the Implementation of Modern Tax Administration System on Taxpayer Compliance
}

\author{
Noldy Chandra ${ }^{1}$, Moh. Dharma Halwi ${ }^{1}$, Rahma Masdar ${ }^{1 *}$, Tampang ${ }^{1}$, \\ Muhammad Din ${ }^{1}$, Nuraela Mapparessa ${ }^{1}$, Lucyani Meldawati ${ }^{1}$ \\ ${ }^{1}$ Department of Accounting, Faculty of Economics and Business, Tadulako University, Palu. \\ *Corresponding author Email: rahmamasdar64@gmail.com
}

\begin{abstract}
This Research aims to determine and analyze the influence of taxpayer awareness, taxation knowledge, and the application of modern taxation administration system to taxpayer compliance. The theory used in this research is the taxpayer owner of the Land Transportation Bureau located in Palu City. The number of samples taken as much as 36 taxpayer owners of the Land Transportation Bureau in Palu City. The data analysis techniques that used in this study were multiple regression analyzes with the help of SPSS program version 21.0. The results of this study showed that taxpayer awareness, taxation knowledge, and the application of modern taxation administration system have a positive and significant effect on taxpayer compliance both partially and simultaneously.
\end{abstract}

Keywords: Taxpayer Awareness, Taxation Knowledge, Application of Modern Taxation Administration System, Taxpayer Compliance

\section{INTRODUCTION}

In recent years, Indonesia is incessantly making findings in an effort to further increase state revenue from the tax sector. In order to realize this, the Indonesian state has carried out modernization of taxation in the taxation sector. Tax modernization carried out by the Directorate General of Taxes (DGT) is a form of tax reform that has been carried out since 1983. The implementation of a modern taxation system is carried out to optimize services to taxpayers. The application of this system includes aspects of the organizational structure, improvement of business processes through the use of communication and information technology, improvement of human resource management, implementation of Good Governance.

Based on the DGT, Central Sulawesi Regional Budget (APBD) in 2017 was 23.6 trillion and the tax revenue is 2.6 trillion rupiah. The office of Palu tax service was still relatively low, only around $50 \%$ of taxpayers who already have a NPWP (Tax Identification Number) that reports the annual SPT (Annual Tax Return). It shows that taxpayers only register NPWP for their business and then they do not report their annual
SPT. There has been a lack of compliance with taxpayers in Palu City in reporting their tax obligations.

The tax payer in Palu has experienced a decrease in tax payments, especially land transportation bureau owners. During the last 4 years there has been an increase and the percentage of tax payments of land transportation bureau owners in Palu City from 2015 to 2018. The percentage of income tax payments was $41.66 \%$, and an increase of $3.12 \%$ in 2016. The percentage of tax payments was $44.78 \%$, in 2017. In 2018, the percentage of tax payments was $54.66 \%$. The percentage of income tax payments for land transportation bureau was finally reached $61.25 \%$. From this explanation, it can be concluded that overall, there has been an increase in the percentage of income tax payments in the last 4 years.

This paper aims to analyse This paper aims to determine the effect of taxpayer awareness, tax knowledge and the application of modern tax administration systems to taxpayer compliance. 


\section{THEORETICAL VIEW HYPHOTESIS DEVELOPMENT}

AND

\subsection{Tax Compliance}

Compliance is a regulation which provides that taxpayers exercise tax rights and comply with tax obligations [1]. There are two forms of enforcement; first, formal compliance is a rule that is in conformity with the law on taxation; second, substantive compliance, that is, material compliance with the contents of the tax law in the form of formal compliance. Tax compliance can be measured using indicators [2], as follows:

1. Taxpayer compliance in registering, namely in the form of the Taxpayer's willingness to register the NPWP.

2. Compliance to re-deposit the SPT is in the form of being on time in paying taxes, knowing the deadline for tax reporting, and the number of tax payment places that can make it easier to pay taxes.

3. Compliance in calculating, calculating, and paying taxes payable, namely in the form of calculating correctly, applying strict sanctions, and tax audits by tax officials.

4. Compliance in reporting and payment of arrears, namely in the form of tax arrears which adds to the tax burden and the willingness of the taxpayer to pay tax arrears.

\subsection{The Effect of Taxpayer Awareness on Taxpayer Compliance}

Consciousness is a factor of people's perception of reality and how to behave and react to that reality. Human consciousness is awareness of oneself or others about the past and the potential future [3]. Taxpayer knowledge is a state under which an individual performs rights and responsibilities in compliance with the terms of the tax legislation. There are several types of tax-paying awareness which encourage taxpayers to pay taxes, and there are three key forms of tax-paying awareness [3]. First, being mindful that taxes are a means of involvement in fostering the growth of a society, taxpayers can be encouraged to pay taxes when they believe that they are not disadvantaged by tax collection. They know that taxes are being used for the growth of the economy and boost the health of the state. Second, understanding that postponing tax payments and reducing tax pressures are very costly to the state. Taxpayers can pay their taxes and they recognize that delays in paying taxes and reducing tax pressures have an effect on a scarcity of financial capital that can impede the growth of the country. Second, understanding that taxes are set down by statute and should be applied. Taxpayers will pay their taxes when they know that paying taxes has a clear legal foundation and is a privilege for any person. Based on this explanation, the following hypothesis is proposed:
$\mathrm{H} 2$ : Taxpayer awareness has a partial effect on taxpayer compliance

\subsection{The Influence of Taxation Knowledge on Taxpayer Compliance}

Tax knowledge is the ability of a taxpayer to know the tax regulations regarding tax rates and also the benefits that are obtained when they pay taxes [4]. Social learning explains that a person's behavior can be influenced by direct experience felt by that person. This can be related to the tax knowledge that a person has. The more learning from observations a person has made about taxation, the more knowledge he has, so that compliance in implementing taxation will increase. This knowledge is information obtained by taxpayers in order to understand and understand information about taxation. Taxpayers who do not understand and understand will tend to disobey and commit fraud in complying with tax regulations.

Conversely, if the taxpayer knows and understand to be the tax itself, indirectly they will be obedient and willing to actively contribute to the implementation of the tax. Tax knowledge is the most influential factor in determining the compliance of taxpayers because if the taxpayer does not have knowledge, it can result in avoiding behavior either intentionally or unintentionally [5]. To be able to increase tax knowledge of taxpayers, one of the efforts that must be made is to disseminate tax regulations, either through counselling or providing a site to access tax regulations. This method is one form of effort to increase the knowledge of the Taxpayer. Taxpayers who already know all applicable tax provisions, taxpayers will easily carry out their tax obligations [6]. Based on this explanation, the following hypothesis is proposed:

H3: Taxation knowledge has partial effect on taxpayer compliance

\subsection{The Effect of the Application of Modern Tax Administration System on Taxpayer Compliance}

The Directorate General of Taxes developed the concept of a modern tax administration system within the framework of medium-term tax administration reform which began in 2002. Basically, the modernization of the tax administration system includes organizational restructuring, improvement of business processes through the use of technology and communication, improvement of HR management, and implementation of Good Governance. The modernization of the administrative system is an important role in the changes made by the Directorate General of Taxes. It is hoped that the renewal of the tax administration system can make it easier for taxpayers. If the existing system has provided satisfaction to the taxpayers, the taxpayers themselves will be more obedient in carrying out their tax obligations. Modernization in the tax administration system positively affects taxpayer compliance 
significantly [7]. The better the implementation of the modern tax administration system carried out by the tax apparatus; the more taxpayers will comply with their tax obligations. Based on this explanation, the following hypothesis is proposed:

H4: Implementation of Modern Tax Administration System Partially Affects Taxpayer Compliance

\section{RESEARCH METHOD}

This research was conducted by sending questionnaires to 49 taxpayers of the Bureau of the Army in Palu City, who are registered with the Transportation Office of Central Sulawesi Province, consisting of corporate taxpayers and individual taxpayers. The data were processed using SPSS multiple regression.

\section{RESULTS}

\subsection{Results of Multiple Linear Regression Analysis}

The output of the SPSS for windows program version 21.0, shows the results of multiple regression in table 1 . Based on the regression coefficient values obtained from the results of the multiple linear regression analysis above, then it is entered into a multiple regression equation model with the following formulations:

$$
Y=-2,939+(0,582 X 1+0,159 X 2+0,140 X 3)+e
$$

Based on the results of the $t$ test obtained, it can be seen that taxpayer awareness has a positive and significant effect on taxpayer compliance. Based on the findings of the researchers, it is clear that the awareness of taxpayers is to participate in an activity to support the country's development. As is well known, the delay in the form of a Taxpayer Identification Number (NPWP) which is used as identification or identity of the taxpayer. These findings are supported by Theory of Planned Behavior (TPB), taxpayers will comply with taxation if they have motivation from the taxpayers themselves. This motivation can grow from the taxpayer, because of the level of knowledge the taxpayer has. Taxation awareness is the degree of which taxpayers have knowledge of tax rights and responsibilities. Identifying tax rights and duties will motivate taxpayers to comply with tax regulations.

The findings of this analysis also conclude that taxpayers' perception has a strong and important impact on taxpayers' compliance. The third hypothesis in this report, which notes that the application of new methods of tax administration has a partial impact on the compliance of taxpayers, is acknowledged. On the basis of the results of this report, the introduction of a new method of tax administration, such as the creation or establishment of a tax service office, the change in the tax information system (SIP) to an integrated tax administration system (SAPT), will make it easier to provide taxation services and make it easier for mandators. tax in the tax compliance process. These findings are supported by psychological theory. According to the psychological theory, the ease of good service from the tax apparatus will increase taxpayer satisfaction with the services provided in fulfilling their tax obligations. To stimulate the willingness to pay taxes, tax administration must be carried out easily, be it easy to get SPT and ease in filling it out. For this reason, efforts to improve taxation services, especially in the context of providing convenience to taxpayers, must continue.

Table 1. Results of Multiple Linear Regression Analysis

\begin{tabular}{|c|c|c|c}
\hline Independent Variables & Regression Coeficient & t- test & Sig. \\
\hline X1 & 0.582 & 2.099 & 0.044 \\
\hline X2 & 0.159 & 2.390 & 0.023 \\
\hline X3 & 0.140 & 2.964 & 0.006 \\
\hline Constanta $=-2,939$ & Adjusted R Square $=0,657$ & \multirow{2}{*}{ Sig. F $=0,000$} \\
\hline Multiple-R $=0,657$ & \multicolumn{2}{|c|}{}
\end{tabular}

paying taxes and reducing the tax burden itself causes the state to suffer losses. So that taxpayers need to understand the tax function for state financing, the tax is determined by law and is compelling.

The findings of this analysis indicate that the awareness and power of taxes have had a substantial positive impact on the compliance of taxpayers. The second hypothesis in this report, which notes that tax awareness has a partial impact on the compliance of taxpayers, is that the socialization carried out by the government through different media makes taxpayers aware that tax is a contribution that must be paid to the State which functions to fund the State. The facilities used in tax administration for taxpayers are provided in

\section{CONCLUSION}

The findings of this study demonstrate the taxpayers' experience, knowledge of taxes and implementation. The New Tax Management System together concurrently influences the compliance of taxpayers. Meanwhile, taxpayers' understanding, tax information and new tax administration structures have partially had a positive and important impact on taxpayers' compliance with land transport offices in Palu Region. The application of a modern tax administration system such as the establishment or establishment of a tax service office, changing the tax information system (SIP) to an integrated tax administration system (SAPT), will make it easier to provide taxation services and make it easier 
for taxpayers in the tax compliance process. The implementation of services and tax audits uses an internal quality control mechanism to be able to build effective communication and get feedback from taxpayers regarding the design, proposals and realization of investment needs in relation to the organization and implementation of a modern tax administration system. The tax service will then review the execution of reorganization, success measurement, evaluation of taxpayers' happiness, and hold daily meetings and input visits. The goal of this implementation is to establish a clean and authoritative government implementation programme.

\section{AUTHORS' CONTRIBUTIONS}

All authors contribute in this research and no potential conflicts.

\section{ACKNOWLEDGMENTS}

This publication was funded by Accounting Department of Tadulako University.

\section{REFERENCES}

[1] A. Rahman, Tax administration implementation guidelines for employees, business actors and companies, Bandung: Nuance, 2010.

[2] A. Gustiyani, "The effect of e-SPT implementation and tax knowledge on tax payer compliance.," Indonesian Computer University Journal of The, 2014.

[3] R. Marjan, The influence of taxpayer awareness, fiskus services, and tax sanctions on the level of taxpayer formal compliance (Study at the South Makassar Pratama), Makassar, Makassar: Department of Accounting, Faculty of Economics and Business, Hasanuddin University., 2014.

[4] I. Cahyadi and I. Jati, "The effect of awareness, outreach, public service accountability and tax sanctions on motor vehicle taxpayer compliance.," E-Journal of Accounting of Udayana University, pp. 2342-2375, 2016.

[5] N. Saad, Tax Knowledge Complexity and Tax Compliance, 2014.

[6] D. Sari, Basic Concept of Taxation, PT. Rafika Aditama., 2013.

[7] S. Rahayu and I. Lingga, "The effect of modernization of tax administration system on corporate taxpayer compliance at KPP Pratama Bandung.," Journal of Accounting, pp. 119-138, 2009. 